in progress are to determine the optimum dosage. Surveys have been earried out to determine the most common eye conditions in different African communities. A higher incidence of non-leprous eye disease was found in lepers in the Central Province than in Lake Province, and this is probably due to trachoma and pterygium being common in the former area. In the foothills of the Ruwenzori Mountains of West Uganda, onchocerciasis is common; it was found that this filarial infection was the most important cause of blindness. Some investigations into the ability of the African to accommodate were made. Although during early life accommodation is poor, it does not deteriorate so rapidly in late middle-life as it does in Europeans. Colour vision was also tested, and it was confirmed that the incidence of red-green and other forms of colour-blindness is lower in Africans than in Europeans.

\section{Diabetes Mellitus in Africans in Rhodesia}

A suRver carried out recently on Salisbury Africans by Dr. M. Gelfand and W. R. Carr indicates that diabetes is less prevalent than in most other parts of the world, particularly in comparison with areas where more processed and highly refined foods are purchased (Central African Journal of Medicine, 7, No. 2; February 1961). The diets with traditionally high carbohydrate, low fat and low animal protein contents are probably the main factor involved in keeping the disease at a low level. There are increas. ingly large numbers of Africans whose diet is changing tremendously during short periods of time towards higher fat, refined sugar and animal protein consumption, but, as yet, they are insufficient in numbers to indicate whether this will have an effect on the incidence of diabetes and, inter alia, coronary thrombosis. The socio-economic background shows that most of the diabetic patients come from groups who work in the European economy, and whose diet has been sltered to include more foods containing, in particular, refined sugar and fats. The clinical types encountered in Rhodesia correspond very closely with the European pattern. No variants such as $J$ or $K$ types are found. The African diabetics may require more insulin than the European for stabilization, but this may be due to lack of understanding of the need to follow a strict dietary routine. The level of blood-sugar was found to be higher than in a European group and this may be the reason for the difference. Although the insulin requirements of the African appeared to be high, hypoglycæmia coma developed if the requirements were exceeded. The symptoms of diabetes appear to be the same for the African and Europeen, the main features being thirst, polyuria, weakness, loss in weight and pruritus vulvæ; but there were certain differences, such as the infrequency of pulmonary tubereulosis, gangrene and intercapillary glomerulosclerosis.

\section{Ecological Aspects of Irrigation in Ancient Meso- potamia}

A PAPER by Hans Helbaek, "Ecological Aspects of Irrigation in Ancient Mesopotamia" (Iraq, 22, 186 ; Spring and Autumn, 1960. Published by the British School of Archæology in Traq), develops the argument that man first harvested his grains (barley and linseed, in particular) where the wild plants grew on hills in the Near East, and on soils fed by rain. Here he supposes the genetic constitution of the crop plants remained fairly constant. But some 7,000 years ago man sowed and grew his wild barley in the plain of Mesopotamia in rich land naturally irrigated by flooding (and later artificially irrigated by canals). Here presently the wild 2-row barley gave rise to a 6-row barley by a moderate genetic change causing the two lateral abortive spikelets to become fertile. Helbaek claims to have produced such a barley as a mutant from a 2-row wild barley by X-ray irradiation. Such 6-row barley was welcomed by early man, and spread to Egypt and elsewhere. Meanwhile, continued irrigation in Mesopotamia led to salt accumulation in the soil and the disappearance of crops, first of the sensitive Emmer wheat, then linseed, and finally of barley, and with that of man. Helbaek gives evidence also that while early man's Linum seeds (whether flax or linseed) remained constant in size for some thousand years by areas fed by rainfall, the size of seed steadily increased in areas with irrigation. Readers interested in the botanical history of crop plants and of the early growth of civilization made possible by crops should read and assess this short paper themselves.

\section{Taxonomy of the Earthworm in India}

EARTHWORMs, apparently sent simultaneously to the British Museum (Natural History) and to the American Museum of Natural History for identification, have directed attention once more to the deplorable state of the taxonomy in a genus that may be dominant in a considerable portion of the Indian Peninsula. Each of the species left in that genus by a revision by G. E. Gates in 1939 , based on an over-all somatic rather than genital anatomy, has remained indefinable hitherto. Material now studied by Gates, at the University of Maine, has enabled recognition not only of two further characters for generic definition but also has permitted, for the first time, fairly satisfactory characterization of a species based on data such as variation in sexual individuals secured in lots of some size from several localities (Ann. Mag. Nat. Hist., 3, No. 35; November 1960). Previously unpublished information included in his account was obtained from 90 specimens collected for him at three localities in the Jubbulpore region during the Second World War.

\section{Geology of the Country around Monmouth and Chepstow}

The Geological Survey of Great Britain has now published a composite Memoir covering the geology of the country around Monmouth and Chepstow (Department of Scientific and Industrial Research Memoirs of the Geological Survey of Great BritainEngland and Wales. By Dr. F. B. A. Welch and Dr. F. M. Trotter. With contributions by T. R. M. Lawrie, J. D. D. Smith and R. W. Elliot. Pp. viii + $164+2$ plates. London: H.M.S.O., 1961. 22s. $6 d$. net). Previously, this area was dealt with in separate Memoirs and Survey sheets, but the present Memoir is an explanation of New Series Geological Sheets 233 (Monmouth) and 250 (Chepstow) -an area occupying a total of 432 square miles, of which some 46 square miles are covered by the Severn Estuary; a little more than half lies within Monmouthshire, part in Herefordshire and the remainder in Gloucestershire. The Memoir details the geological sequence and history of the area, which extends from the Ludlow Series of the Silurian rocks through Old Red Sandstone, Carboniferous, Triassic, Jurassic to recent superficial formations. A general account of the 